\title{
Using Digital Technologies in Response to the COVID-19 Pandemic in Portugal
}

\author{
Diana Portela $^{a}$ Duarte Vital Brito ${ }^{b}$ Hugo Monteiro ${ }^{c}$ \\ ${ }^{a}$ ACES Entre o Douro e Vouga I - Feira/Arouca, Faculdade de Medicina da Universidade do Porto, Porto, \\ Portugal; ' Unidade de Saúde Pública do Agrupamento de Centros de Saúde de Lisboa Central, Lisbon, Portugal; \\ 'Departamento de Estudos e Planeamento da Administração Regional de Saúde do Norte, Porto, Portugal
}

\section{Keywords}

Public health informatics · Digital technology · Knowledge management $\cdot$ Information technologies · COVID-19

\begin{abstract}
Digital technologies revolutionized the way we dealt with the COVID-19 pandemic and outstood the obvious societal change in the information age. Currently, data are an essential element of any health institution. Their use has the potential to radically reduce the cost and time needed to strengthen scientific evidence on the effectiveness of interventions. Likewise, information and the potential of these technologies have become a crucial part of the response to the pandemic. Effective implementation of data management strategies has depended on the adoption of digital technologies and their integration with health policies and care systems. In August 2020, Nature Medicine published an article about technological maturity and digital responses in the context of the COVID-19 pandemic. This paper aims to provide a contextualization of the technologies adopted in Portugal in the current crisis while highlighting, when applicable, requirements, potentials, constraints and aspects of possible improvements. The digital maturity of health services is a gradual process that requires preparation, adapta-
\end{abstract}

tion and response. The future of public health and health care systems will be increasingly digital, and it is necessary to promote a culture of innovation, coordinate and standardize processes and make room for a new paradigm of sustainable digital transformation.

(C) 2022 The Author(s). Published by S. Karger AG, Basel on behalf of NOVA National School of Public Health

\section{O uso de tecnologias digitais na resposta à pandemia de COVID-19 em Portugal}

Palavras Chave

Informática de saúde pública - Tecnologias digitais . Gestão do conhecimento · Tecnologias de informação . COVID-19

\section{Resumo}

As tecnologias digitais revolucionaram a forma como lidamos com a pandemia da COVID-19, tornando-se evidente a mudança de toda a sociedade na era da informação. Atualmente, os dados são um elemento essencial de qualquer instituição de saúde. O seu uso tem o potencial de reduzir radicalmente o custo e o tempo necessários para (c) 2022 The Author(s). Published by S. Karger AG, Basel on behalf of NOVA National School of Public Health

This is an Open Access article licensed under the Creative Commons Attribution-NonCommercial-4.0 International License (CC BY-NC) (http://www.karger.com/Services/OpenAccessLicense), applicable to the online version of the article only. Usage and distribution for commercial purposes requires written permission.
Correspondence to:

Diana Portela, di.portelasilva@gmail.com 
fundamentar evidência científica sobre a eficácia das intervenções. Da mesma forma, a informação e potencial tecnológico tornaram-se parte crucial da resposta à pandemia e a implementação eficaz de estratégias de gestão de dados dependeu da adoção de tecnologias digitais e a sua integração com as políticas e cuidados de saúde. Em agosto de 2020, a Nature Medicine publicou um artigo sobre situação de maturidade tecnológica e respostas digitais no contexto da pandemia de COVID-19. Neste sentido, pretendemos contextualizar as tecnologias adoptadas em Portugal na situação de crise atual, realçando, quando aplicável, os requisitos, potenciais, constrangimentos e aspetos de possíveis melhorias. A maturidade digital envolve congruência, preparação, capacidade, infraestrutura e planeamento estratégico com foco nos resultados de saúde. O futuro da saúde pública, e dos sistemas e cuidados de saúde será cada vez mais digital, pelo que, é necessário promover uma cultura de inovação, com processos coordenados e padronizados e criando espaço para um novo paradigma de transformação digital sustentável. @ 2022 The Author(s). Published by S. Karger AG, Basel on behalf of NOVA National School of Public Health

\section{Context}

Digital technologies revolutionized the way we dealt with the COVID-19 pandemic and outstood the obvious societal change in the information age. Nowadays we have an abundant production of information, which requires the use of new methodologies to organize data, operational planning, reporting and epidemiological surveillance, including the notification and early detection of communicable diseases and screening of close contacts, among other public health-related activities. The COVID-19 pandemic accelerated the digital transformation in health care and brought a unique opportunity to instigate the use of these new technologies in health services. This iterative process of innovation through digital technologies has integrated a dynamic development of cultural change, a commitment to promote and maintain health, in the quest for continuous improvement of quality and user satisfaction in the context of a public health emergency [1].

According to the National Statistics Institute, about $76 \%$ of the population living in Portugal between 16 and 74 years old use the Internet, and $80 \%$ of these users participate in social networks [2]. Society is connected, enabling the real-time sharing of a wide range of information as the location of cases and their so- ciodemographic characteristics - highly important in the present scenario. The integration of such information with institutional data allows mapping geographic dispersion of cases, the geographical circuit of genomic sequencing of the viruses found, implementing advanced mathematical modelling of the evolution of cases in the various regions, sharing of best practices and multicentre clinical studies on a global scale. The value of real-world data analysis is evident for planning, intervention and validation of strategy. This continuous collection of information in real time allows the development of research, supporting timely decision-making and promoting the drafting of updated rules and guidelines, whose implemented strategies enhance good practices [3]. Nevertheless, as data volume increases, so does its complexity which requires computational power and advanced analytical tools.

Currently, data are an essential element of any health institution. Their use has the potential to radically reduce the cost and time needed to strengthen scientific evidence on the effectiveness of interventions. In addition to supporting evidence-based decision-making, the range of applicability of these data is vast and has already been previously described in the literature $[4,5]$. From a public health perspective, properly monitoring and governance of such data require the adoption and implementation of digital technologies, which, on the other hand, require a robust public health infrastructure. A robust public health infrastructure should be envisioned as a framework composed of three interconnected systems: organizations (governmental and non-governmental entities), people (public health workforce) and information and communications technologies (hardware, software and devices that capture, store, manage, exchange, and create data and information). The lack of such infrastructure compromises the implementation, adoption and validity of the usage of digital technologies. Moreover, such an investment should be complemented with proper public health professionals training on digital health, both during undergraduate and postgraduate education. This is especially important in moments that stress the system and rise the question: "Are we prepared to maximize the potential of digital technologies and data management during the COVID-19 pandemic?" To fill the gap in the literature, this paper aims to provide a contextualization of the technologies adopted in Portugal in the current crisis, while highlighting, when applicable, requirements, potentials, constraints and aspects of possible improvements. 
Table 1. Digital technologies used in the COVID-19 public health interventions in Portugal

\begin{tabular}{|c|c|c|c|c|}
\hline $\begin{array}{l}\text { Public health } \\
\text { intervention need }\end{array}$ & Type of intervention & $\begin{array}{l}\text { Name of the intervention } \\
\text { tool }\end{array}$ & Use type & Potential areas for improvement \\
\hline \multirow[t]{2}{*}{$\begin{array}{l}\text { Epidemiological } \\
\text { surveillance }\end{array}$} & Contact tracing & $\begin{array}{l}\text { SINAVE } \\
\text { TraceCOVID }\end{array}$ & $\begin{array}{l}\text { Contact tracing } \\
\text { management and case } \\
\text { notification }\end{array}$ & $\begin{array}{l}\text { Workflow optimization, geomapping improvement } \\
\text { in multiple used platforms and adoption of } \\
\text { real-world operations perspective }\end{array}$ \\
\hline & Clinical follow-up & TraceCOVID & $\begin{array}{l}\text { Identified case surveillance } \\
\text { and contact tracing }\end{array}$ & $\begin{array}{l}\text { Patient-centred process optimization, adoption of a } \\
\text { more operational-focused perspective that allows a } \\
\text { better worker allocation to specific jobs, } \\
\text { documentation and online messaging workflow } \\
\text { optimization }\end{array}$ \\
\hline \multirow[t]{4}{*}{ Data analysis } & $\begin{array}{l}\text { Tools for data } \\
\text { visualization }\end{array}$ & $\begin{array}{l}\text { TraceCOVID BI dashboard, } \\
\text { at national level }\end{array}$ & $\begin{array}{l}\text { Decision support and } \\
\text { communication to general } \\
\text { population }\end{array}$ & $\begin{array}{l}\text { Relevant data mining and selection for further } \\
\text { research, optimization of data collection, inclusion of } \\
\text { public health intervention evaluation, automation of } \\
\text { report production for decision-makers }\end{array}$ \\
\hline & $\begin{array}{l}\text { Systems for } \\
\text { automatic reading }\end{array}$ & - & - & Manual input automation \\
\hline & $\begin{array}{l}\text { Wearables and } \\
\text { biosensors }\end{array}$ & $\begin{array}{l}\text { Body temperature } \\
\text { measure by biosensors }\end{array}$ & Symptom monitoring & Scaling up to manual labour and school settings \\
\hline & $\begin{array}{l}\text { Digital and genomic } \\
\text { diagnostics }\end{array}$ & - & - & $\begin{array}{l}\text { Faster diagnostics and support for scientific evidence } \\
\text { production }\end{array}$ \\
\hline Data privacy & $\begin{array}{l}\text { Technologies for } \\
\text { privacy and safety }\end{array}$ & - & - & $\begin{array}{l}\text { Ensure security in sharing health data between users } \\
\text { and institutions }\end{array}$ \\
\hline \multirow[t]{6}{*}{ Communication } & Smartphone apps & StayAway COVID & $\begin{array}{l}\text { Identification of high-risk } \\
\text { contacts }\end{array}$ & $\begin{array}{l}\text { Identification of date of contact with a confirmed } \\
\text { case and process simplification by the physician }\end{array}$ \\
\hline & Online forms & $\begin{array}{l}\text { TraceCOVID (self- } \\
\text { reporting symptoms), } \\
\text { Microsoft forms }\end{array}$ & $\begin{array}{l}\text { Surveillance, contact } \\
\text { tracking and } \\
\text { epidemiological surveys }\end{array}$ & $\begin{array}{l}\text { Automatic translation, information loading directly } \\
\text { to TraceCOVID and SINAVE platforms }\end{array}$ \\
\hline & E-mail & Microsoft Outlook & $\begin{array}{l}\text { Communication with the } \\
\text { user }\end{array}$ & $\begin{array}{l}\text { Training on best practices and organization of } \\
\text { mailboxes }\end{array}$ \\
\hline & SMS & $\begin{array}{l}\text { Systematized sending in } \\
\text { TraceCOVID }\end{array}$ & $\begin{array}{l}\text { Communication with the } \\
\text { user }\end{array}$ & Collection of responses from users by SMS \\
\hline & $\begin{array}{l}\text { Social media and } \\
\text { online research }\end{array}$ & $\begin{array}{l}\text { COVID-19 barometer } \\
\text { (ENSP) and risk perception } \\
\text { research (DGS) }\end{array}$ & $\begin{array}{l}\text { Online questionnaire on } \\
\text { behaviours, attitudes and } \\
\text { perceptions }\end{array}$ & Chatbot to clarify doubts and recommendations \\
\hline & Telehealth & Ms Teams and Zoom & $\begin{array}{l}\text { Organizational, internal } \\
\text { and external } \\
\text { communication }\end{array}$ & $\begin{array}{l}\text { Improvement, integration with analytical tools for } \\
\text { improved collaboration, data lakes for data science } \\
\text { collaboration and dynamic feedback }\end{array}$ \\
\hline
\end{tabular}

SINAVE, National Epidemiological Surveillance System; ENSP, National School of Public Health; DGS, General-Directorate of Health.

\section{Methods and Results}

In August 2020, Nature Medicine published an article about technological maturity and digital responses in the context of the COVID-19 pandemic [6]. There is a granularity in national management and local challenges in technology adoption. Given the scarcity of information and investigations on the topic, a qualitative methodology was considered more appropriate. The research involved a literature and operational practices review across different contexts and services as well as expert's opinions to systematize a contextualization of the technologies adopted in Portugal in the current crisis. Likewise, we provide an overview of collected data while highlighting as- 
pects of possible improvements. Through a comparative data analysis approach, we identify 4 major areas in need of public intervention (epidemiological surveillance, data analysis, data privacy and communication). We, then, subset the type of intervention and the adopted tool in Portugal for this purpose during the pandemic. Further details are described in Table 1, as well as the identified areas of improvement.

\section{Discussion}

Since the beginning of the pandemic, one of the main lessons learned is the urgent need to accelerate the digital maturity of our health systems. The improvement of the health and well-being of our citizens and the protection of our health professionals will be achieved by building resilient health care during and after the current crisis. However, there is an increasing gap between where we are and where we want to be as digital maturity goes beyond innovation per se. The constant changes in the way technology can be used require a culture of agile, iterative and interactive innovation [7]. The digital maturity of health services is a gradual process that requires preparation, adaptation and response. Innovation is not a static process that occurs in a moment and modifies the clinical practice or the way the clinical and therapeutic decision-making process is developed. Nevertheless, it should always aim for efficiency, safety and health gains, in a format that is intended to be constructive and not disruptive. In their simplest form, roadmaps for digital maturity are achieved by assessing the ability and compatibility of information systems to communicate with each other or as an interface within and between organizations. Many have been proposed and demonstrate the unique needs of the systems in question.

In Portugal, to achieve this potential, it is necessary to create solid foundations in the digital architecture of the system and health care, essential for the successful use of technology, as individual and collectively designed information systems to interact. Among the central pillars of digital maturity, user needs, privacy and security, interoperability and inclusion stand out. Hence, this also reinforces the urgent need for robust public health infrastructure. Any technological adoption or service must be built around the user and respond, in the first instance, to their needs. Such a perspective will reduce costs by increasing the potential to be adopted by the final consumer, either patients or health professionals. It is critical to ensure privacy and security through the creation of stan- dards and guidelines that enhance the trust and transparency of the digitization process, especially in health. Interoperability is defined as "the ability of two or more electronic health record systems or health information technology components to exchange information and to use the information that has been exchanged" [8]. Essential elements of interoperability lie in linking different data sources to a pattern of united identifiers that make individuals traceable. Interoperability has implications for providing reliable results, minimizing errors and costs and optimizing system operation. There are points of multichannel interaction that created opportunities for the integration of systems such as Trace COVID-19 and the National Epidemiological Surveillance System (SINAVE) [9]. Nevertheless, the stress on such systems is outstanding the evidence on their lack of integration. A study performed on these platforms highlighted their low data quality leading to inaccurate results and limited evidence produced [10].

In addition, different people have different service needs, and individuals with the most needs are those most at risk of being excluded by digital services, so awareness of inclusion and increased accessibility is necessary - not forgetting the digital health literacy of these groups. In an ecosystem of limited resources, these principles aim to guarantee the sustainability of the technologies adopted - guaranteeing their cost-efficiency. It is imperative that recommendations on technologies such as mobile phone applications, such as StayAwayCOVID or other wearable devices that are tailored for specific problems, be based on scientific premises that justify their investment. Another advantage of digital technologies is their use to reduce inequalities, taking into consideration the existing digital divide. But to achieve this, efforts and strategies will have to be created to promote digital health literacy among citizens and health professionals.

Health technologies are a practical application of knowledge to improve or maintain individual and population health. There is a growing collision and inclusion of digital health technologies as a specific domain. Likewise, they will be required to undergo the implementation of a full lifecycle of assessment, appraisal and evaluation. To promote new digital technologies, their usefulness must be clarified, the concepts properly defined, and the impact measured. Aligned with the lack of standards and regulation, it would also be beneficial to integrate concepts such as, by example, epidemiological intelligence into health semantics dictionaries [11]. 


\section{Conclusions}

The future of public health and health care systems will be increasingly digital, making it necessary to create a culture of innovation, coordinated and standardized processes, while making room for a competitive market with equal opportunities. It is not just about implementing more and better technologies. The need for a robust public health infrastructure shall also be envisioned. The universe of digital technologies has a development cycle and implementation much faster than other technologies. When a new technology is validated, another one can replace it quickly. Digital maturity involves congruence, preparation, capacity, infrastructure and strategic planning with a focus on health outcomes. To this end, it is necessary to change the static paradigm of digital transformation to a dynamic digital maturity of health systems, creating a safe, sustainable and intelligent future for health systems, capable of reducing errors and promoting the quality and safety of patients [8]. Digital technology is expanding, and has two major values for public health: it can provide quick actionable insights allowing to deal with complex planning projects and support precise public health interventions, and it can capacitate populations to stay informed and collaborate in improving their health status.

\section{Conflict of Interest Statement}

The authors have no conflicts of interest to declare.

\section{Funding Sources}

The authors received no financial support for the research, authorship and publication of this article.

\section{Author Contributions}

All authors contributed equally to this paper.

\section{References}

1 De' R, Pandey N, Pal A. Impact of digital surge during Covid-19 pandemic: a viewpoint on research and practice. Int J Inf Manage. 2020; 55:102171.

2 Instituto Nacional de Estatística. À utilização de tecnologias da informação e da comunicação pelas famílias 2019. Destaque: informação à comunicação social. Lisboa: Instituto Nacional de Estatística; 2019.

3 Ahern S, Feiler R, Sdrinis S. Maximising the value of clinical registry information through integration with a health service clinical governance framework: a case study. Aust Health Rev. 2020;44(3):421-6.
4 Bhardwaj N, Wodajo B, Spano A, Neal S, Coustasse A. The impact of big data on chronic disease management. Health Care Manag. 2018;37(1):90-8.

5 Ho YF, Hu FC, Lee PI. The advantages and challenges of using real-world data for patient care. Clin Transl Sci. 2020;13(1):4-7.

6 Budd J, Miller BS, Manning EM, Lampos V, Zhuang M, Edelstein M, et al. Digital technologies in the public-health response to COVID-19. Nat Med. 2020;26(8):1183-92.

7 Rogers DL. The digital transformation playbook: rethink your business for the digital age. New York: Columbia Business School Publishing; 2016.
8 Magnuson JA, Fu PC. Public health informatics and information systems. Berlin: Springer International Publishing; 2020.

9 Portugal Ministério da Saúde, Direção-Geral da Saúde. Norma 015/2020 de 24/07/2020: COVID-19: rastreio de contactos. Lisboa: Direção-Geral da Saúde; 2020.

10 Costa-Santos C, Luísa Neves A, Correia R, Santos P, Monteiro-Soares M, Freitas A, et al. COVID-19 surveillance: a descriptive study on data quality issues. MedRxiv. 2020.

11 Martins JNP. Semântica da informação em saúde 2017. Lisboa: Direção de Serviços de Informação e Análise, Direção-Geral da Saúde; 2017. 